\title{
Does size matter? Technical considerations of a regenerative tissue matrix for use in reconstructive surgery
}

\author{
Randall O Craft MD ${ }^{1}$, Alanna M Rebecca MD², Colleen Flahive $\mathrm{BSc}^{2}$, \\ William J Casey III MD², Amylou Dueck PhD², Kristi L Harold MD²
}

RO Craft, AM Rebecca, C Flahive, WJ Casey III, A Dueck, KL Harold. Does size matter? Technical considerations of a regenerative tissue matrix for use in reconstructive surgery. Can J Plast Surg 2011;19(2):51-52.

INTRODUCTION: Acellular dermal matrices have been used with increasing frequency in both reconstructive and cosmetic surgery. While many studies have described the safety and morbidity profiles of these materials, little is known about the relative mechanical properties of individual sheets of allograft harvested from distinct donors.

METHODS: Sixty-two individual sheets of an acellular dermal matrix from distinct lot numbers (signifying different donors of the dermis) were prospectively analyzed before use. Distribution of thickness according to manufacturer specifications in the dry state were as follows: 0.009 inches to 0.013 inches (1 [1.6\%]); $0.79 \mathrm{~mm}$ to $1.78 \mathrm{~mm}$ (3 [4.8\%]); $0.79 \mathrm{~mm}$ to $2.03 \mathrm{~mm}$ (5[8\%]); $0.8 \mathrm{~mm}$ to $3.3 \mathrm{~mm}$ (1 [1.6\%]); $1.8 \mathrm{~mm}$ to $3.3 \mathrm{~mm}$ $(10[16.1 \%])$ and $28 \mathrm{~mm}(6[9.7 \%])$. The size of the matrix was recorded while dry, after hydration and following stretch. The percentage change in surface area was recorded for each lot.

RESULTS: The 62 reconstructive cases included breast implant reconstruction (2 [3.2\%]); ventral hernia repair (11 [17.7\%]); abdominal closure following autologous tissue harvest (6 [9.6\%]); autologous breast reconstruction (37 [59.6\%]); extremity wound closures (3 [4.8\%]) and reinforcement of vertical rectus abdominis muscle closure $(3[4.8 \%])$. The mean percentage change in the size of the acellular dermal matrix to the hydrated state was $58 \%$ ( 36 of 62 ; thickness $0.06 \mathrm{~mm}$ to $3.30 \mathrm{~mm}$ ); the mean percentage change in size from dry state was $7.14 \%$ (range $0 \%$ to $18.7 \%$ ). The mean percentage change in the size of the hydrated matrix to the stretched state was $25.7 \%$ (range $0.25 \%$ to $70.6 \%$ ). The variability in elasticity among the individual sheets was significant $(\mathrm{P}<0.0005)$.

CONCLUSION: The acellular dermal matrix displayed highly variable elastic properties among distinct donors. This may be significant in procedures in which symmetry is critical.

Key Words: Acellular dermis; AlloDerm; Biological; Reconstructive

\section{La dimension compte-t-elle? Des considérations techniques au sujet d'une matrice de tissu régénératif à utiliser en chirurgie reconstructive}

INTRODUCTION : Les matrices dermiques acellulaires sont de plus en plus utilisées, tant en chirurgie reconstructive qu'en chirurgie esthétique. De nombreuses études ont décrit les profils d'innocuité et de morbidité de ces matières, mais on ne sait pas grand-chose des propriétés mécaniques relatives des feuilles individuelles d'allogreffe prélevée sur des donneurs distincts.

MÉTHODOLOGIE : Soixante-deux feuilles individuelles de matrice dermique acellulaire provenant de numéros de lots distincts (signifiant des donneurs de derme différents) ont fait l'objet d'une analyse prospective avant leur utilisation. La répartition de l'épaisseur selon les spécifications du fabricant à l'état sec s'établissent comme suit : 0,009 po à 0,013 po (1 [1,6 \%]); 0,79 mm à $1,78 \mathrm{~mm}(3$ [4,8 \%]); $0,79 \mathrm{~mm}$ à 2,03 mm (5 [8 \%]); $0,8 \mathrm{~mm}$ à $3,3 \mathrm{~mm}(1[1,6 \%]) ; 1,8 \mathrm{~mm}$ à $3,3 \mathrm{~mm}(10$ [16,1\%]) et $28 \mathrm{~mm}$ (6 [9,7\%]). Les chercheurs ont enregistré la dimension de la matrice alors qu'elle était sèche, après l'avoir hydratée et après l'avoir étirée. Ils ont enregistré le changement de pourcentage de la surface pour chaque lot.

RÉSULTATS : Les 62 cas de chirurgie reconstructive ont inclus des reconstructions par implant mammaire $(2[3,2 \%])$, des réparations de hernie ventrale $(11[17,7 \%])$, des fermetures abdominales après prélèvement de tissu autologue $(6[9,6 \%])$, des reconstructions mammaires par tissus autologues (37 [59,6\%]), des fermetures de plaies aux membres $(3[4,8 \%])$ et le renforcement de fermetures verticales du muscle grand droit de l'abdomen (3 [4,8 \%]). Le changement de pourcentage moyen de la dimension de la matrice dermique acellulaire à l'état d'hydratation était de $58 \%$ (36 sur 62; épaisseur $0,06 \mathrm{~mm}$ à $3,30 \mathrm{~mm}$ ); le changement de pourcentage moyen de la dimension à partir de l'état sec était de 7,14\% (plage de $0 \%$ à $18,7 \%$ ). Le changement de pourcentage moyen de dimension de la matrice hydratée à l'état étiré était de 25,7\% (plage de 0,25\% à 70,6\%). On constatait une variabilité importante de l'élasticité entre chaque feuille $(\mathrm{P}<0,0005)$.

CONCLUSION : La matrice dermique acellulaire présentait des propriétés d'élasticité très variables selon les divers donneurs. Ce constat peut être important dans le cadre d'interventions où la symétrie est essentielle.
A

loderm (LifeCell Corporation, USA) is an acellular dermal matrix widely used in abdominal wall reconstruction (1), facial plastic surgery (2-5), gynecological and urological surgery (6-8), and breast reconstruction (9-11). In addition to a multitude of clinical series, animal studies $(12,13)$ have demonstrated both its safety and clinical efficacy as a tissue substitute. While independent studies (3) have demonstrated that the tensile strength or maximal load to failure of AlloDerm is superior to both autologous tissue and expanded polytetrafluoroethylene, only recently have studies (14) emerged reporting the elastic properties of AlloDerm. Nahabedian (14) described a 75\% increase in the surface area of revascularized AlloDerm when used in abdominal wall repair. Although the product specifications indicate up to $50 \%$ stretch in the hydrated state, no data are available regarding the differences in elasticity between individual products harvested from different donors. Given the variability of clinical outcomes reported with the use of AlloDerm for reconstructive procedures, we hypothesized that different elastic properties of the material among different donors (ie, different product lot numbers) would be of clinical relevance.

\section{PATIENTS AND METHODS}

Sixty-two individual sheets of AlloDerm from distinct lot numbers (signifying different donors of cadaveric tissue) were prospectively analyzed before use in reconstructive surgery. Distribution of thickness according to manufacturer specifications in the dry state were as follows: 0.009 inches to 0.013 inches $(1[1.6 \%]) ; 0.79 \mathrm{~mm}$ to $1.78 \mathrm{~mm}$ (3 [4.8\%]); $0.79 \mathrm{~mm}$ to $2.03 \mathrm{~mm}$ (5 [8\%]); $0.8 \mathrm{~mm}$ to $3.3 \mathrm{~mm}$ (1 [1.6\%]); $1.8 \mathrm{~mm}$ to $3.3 \mathrm{~mm}(10[16.1 \%])$ and $28 \mathrm{~mm}(6[9.7 \%])$. The size of the 
matrix was recorded while dry, after hydration and following stretch. The percentage change in surface area was recorded for each lot.

\section{RESULTS}

The 62 reconstructive cases included breast implant reconstruction (2 [3.2\%]); ventral hernia repair (11 [17.7\%]); abdominal closure following autologous tissue harvest (6 [9.6\%]); autologous breast reconstruction (37 [59.6\%]); extremity wound closures (3 [4.8\%]) and reinforcement of vertical rectus abdominis muscle closure (3 [4.8\%]). The mean percentage change in the size of Alloderm to the hydrated state was $58 \%$ ( 36 of 62 ; thickness $2.06 \mathrm{~mm}$ to $3.30 \mathrm{~mm}$ ), and the mean percentage change in size from dry state was $7.14 \%$ (range $0 \%$ to $18.7 \%$ ). The mean percentage change in the size of hydrated Alloderm to the stretched state was $25.7 \%$ (range $0.25 \%$ to $70.6 \%$ ). The variability in elasticity among the individual sheets of Alloderm was highly significant $(\mathrm{P}<0.0005)$.

\section{DISCUSSION}

AlloDerm is an acellular human dermal tissue matrix that has been described in a wide variety of clinical scenarios including reconstructive procedures and reinforcement of areas of tissue laxity. However, reported outcomes have been highly variable. Early analysis of the biomechanical properties of Alloderm compared with both synthetic mesh and autologous tissue demonstrated superior tensile strength or load to failure for Alloderm (8). Nahabedian (14) described a case of vascularized AlloDerm retrieved after use for repair of abdominal wall laxity following deep inferior epigastric perforator breast reconstruction. He found a $75 \%$ increase in the mesh surface area based on an initial area of $68 \mathrm{~cm}^{2}$ and a subsequent area of $119 \mathrm{~cm}^{2}$ at retrieval. The elastic potential of Alloderm had been assumed to be negligible given the reported cumulative recurrence rate of $3.7 \%$ when used for the repair of complex abdominal wall hernias. However, when used for reconstruction of anterior vaginal wall prolapse, a $50 \%$ failure rate was reported based on objective evaluation for stage II prolapse (6).

Variability in clinical outcomes has been attributed to a variety of technical considerations in the initial application of AlloDerm including inlay versus onlay, orientation of the basement membrane and the amount of stretch on the prosthetic during time of placement (10). Although initial reports indicated that AlloDerm was most effective when placed as an inlay (15), subsequent work (16) has shown that it

\section{REFERENCES}

1. de Moya MA, Dunham M, Inaba K, et al. Long-term outcome of acellular dermal matrix when used for large traumatic open abdomen. J Trauma 2008;65:349-53.

2. Sachsman SM, Rice DH. Use of AlloDerm implant to improve cosmesis after parotidectomy. Ear Nose Throat J 2007;86:512-3.

3. Morgan AS, McIff T, Park DL, Tsue TT, Kriet JD.

Biomechanical properties of materials used in static facial suspension. Arch Facial Plast Surg 2004;6:308-10.

4. Taban M, Douglas R, Li T, Goldberg RA, Shorr N. Efficacy of "thick" acellular human dermis (AlloDerm) for lower eyelid reconstruction: Comparison with hard palate and thin AlloDerm grafts. Arch Facial Plast Surg 2005;7:38-44.

5. Vural E, McLaughlin N, Hogue WR, Suva LJ. Comparison of biomechanical properties of alloderm and enduragen as static facial sling biomaterials. Laryngoscope 2006;116:394-6.

6. Clemons JL, Myers DL, Aguilar VC, Arya LA. Vaginal paravaginal repair with an AlloDerm graft. Am J Obstet Gynecol 2003;189:1612-8; discussion 8-9.

7. Lemer ML, Chaikin DC, Blaivas JG. Tissue strength analysis of autologous and cadaveric allografts for the pubovaginal sling. Neurourol Urodyn 1999;18:497-503.

8. Choe JM, Kothandapani R, James L, Bowling D. Autologous, cadaveric, and synthetic materials used in sling surgery: Comparative biomechanical analysis. Urology 2001;58:482-6.

9. Preminger BA, McCarthy CM, Hu QY, Mehrara BJ, Disa JJ. The influence of AlloDerm on expander dynamics and complications is equally effective when placed in the onlay position. Furthermore, Butler and Prieto (17) demonstrated revascularization that was independent of the orientation of the basement membrane. They also demonstrated an increased tendency for AlloDerm to stretch when placed with little to no tension (15). However, the ideal amount of tension has not been determined (14). Nahabedian (14) demonstrated that a vascularized sheet of AlloDerm can stretch up to $75 \%$ in vivo, contradicting the assumption that the stretch after incorporation was negligible.

It is important to remember that AlloDerm is harvested from human dermis and is, therefore, composed of collagen, elastin, hyaluronan, proteoglycans, fibronectin and a vascular framework (14). LifeCell's proprietary processing preserves the extracellular matrix without crosslinking, theoretically allowing for better cellular migration and tissue regeneration. However, it is also possible that preservation of the native collagen framework may contribute to a variable amount of elasticity in the product, reflecting the differing tissue properties of the donor dermis. Accordingly, our practice has tended toward using AlloDerm from a single lot number (signifying a single donor) in breast reconstruction or in other procedures in which the aim is to have uniform elasticity to achieve symmetry. Furthermore, the hydrated, nonvascularized variability in elasticity may explain Nahabedian's report of a single sheet of AlloDerm exhibiting stretch up to $75 \%$, as our own series demonstrated a range of $0.25 \%$ to $71 \%$. Finally, this may lend credence to the findings that LifeCell's latest product, Strattice, may be better suited for abdominal wall reconstruction due to its reported relative lack of elasticity compared with AlloDerm. Although the processing is identical, the donor dermis is porcine, and likely less variable than the human donors used for AlloDerm. The clinical relevance of the different elastic properties of these biologics needs to be examined in additional studies.

\section{CONCLUSION}

The elastic properties of Alloderm vary widely among products harvested from different donors. Although the manufacturer cites up to $50 \%$ stretch in the hydrated state, we observed a mean of $25.7 \%$ (range $0.25 \%$ to $70.6 \%$ ); the mean differences in stretch were highly significant $(\mathrm{P}<0.0005)$. Such differences in the tensile and elastic properties among different lot numbers of this product may have clinical significance, especially in breast reconstruction, in which symmetry is critical for a satisfactory patient outcome.

in the setting of immediate tissue expander/implant reconstruction: A matched-cohort study. Ann Plast Surg 2008;60:510-3.

10. Nahabedian MY. Secondary nipple reconstruction using local flaps and AlloDerm. Plast Reconstr Surg 2005;115:2056-61.

11. Colwell AS, Breuing KH. Improving shape and symmetry in mastopexy with autologous or cadaveric dermal slings. Ann Plast Surg 2008;61:138-42.

12. Menon NG, Rodriguez ED, Byrnes CK, Girotto JA, Goldberg NH, Silverman RP. Revascularization of human acellular dermis in full-thickness abdominal wall reconstruction in the rabbit model. Ann Plast Surg 2003;50:523-7.

13. Silverman RP, Li EN, Holton LH III, Sawan KT, Goldberg NH. Ventral hernia repair using allogenic acellular dermal matrix in a swine model. Hernia 2004;8:336-42.

14. Nahabedian MY. Does AlloDerm stretch? Plast Reconstr Surg 2007;120:1276-80.

15. Butler CE, Langstein HN, Kronowitz SJ. Pelvic, abdominal, and chest wall reconstruction with AlloDerm in patients at increased risk for mesh-related complications. Plast Reconstr Surg 2005;116:1263-75; discussion 1276-7.

16. Buinewicz B, Rosen B. Acellular cadaveric dermis (AlloDerm): A new alternative for abdominal hernia repair. Ann Plast Surg 2004;52:188-94.

17. Butler CE, Prieto VG. Reduction of adhesions with composite AlloDerm/polypropylene mesh implants for abdominal wall reconstruction. Plast Reconstr Surg 2004;114:464-73. 